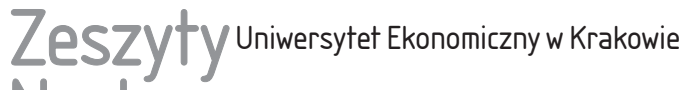 Naukowe
}

\section{The Similarities and Differences between Earnings Management and Fraud}

\begin{abstract}
Objective: The main objective of this article is to indicate differences between earnings management and fraud.

Research Design \& Methods: The research methods applied are based on a critical analysis of the literature on the subject, both in Polish and English, a comparative analysis of legal acts and inductive reasoning.

Findings: Earnings management involves intentional and lawful actions undertaken by an entity's management, aimed at changing the figures it reports, particularly earnings, in order to present the desired picture of the entity's financial standing and economic position, as well as its achievements in financial statements for the purpose of misleading financial statement users or obtaining benefits guaranteed in managerial contracts. This is achieved by applying accounting judgment and estimates, changing these estimates, choosing specific methods from among the acceptable accounting methods allowed by the applicable accounting regulations, structuring of economic transactions or undertaking actual activities.

Implications / Recommendations: Earnings management should not be identified with fraud, as earnings are managed within the framework of legal regulations in the field of
\end{abstract}

Sylwia Czakowska, Kujawy and Pomorze University in Bydgoszcz, Institute of Economics, Department of Finance and Accounting, Toruńska 55-57, 85-023 Bydgoszcz, e-mail: s.czakowska@ kpsw.edu.pl, ORCID: https://orcid.org/0000-0003-3956-8966.

This is an open access article distributed under the terms of the Creative Commons Attribution-NonCommercial-NoDerivatives 4.0 License (CC BY-NC-ND 4.0); https://creativecommons.org/ licenses/by-nc-nd/4.0/ 
accounting and taking account of solutions adopted in the accounting policy of a given entity. However, any abuse in this field, whether it involves departing from or violating the accounting principles or standards, may lead to intentional misstatements in financial statements - that is, fraud in its broad sense.

Contribution: Inspiring further development of research on earnings management from the viewpoint of determinants or tools applied.

Keywords: earnings management, financial statement, fraud, fraudulent financial reporting.

JEL Classification: M41, M42.

\section{Introduction}

Economic crises and recessions experienced by a number of sectors and the deterioration of the financial situation and profitability of enterprises are compelling reasons for management boards to undertake actions aimed at managing their earnings so that they achieve the desired level by way of influencing the amounts of revenues and expenses, as well their distribution over time (Kuzior 2011, p. 175). Consequently, financial statements present the financial data management expects, which can be used to influence stakeholders and motivate them to undertake specific actions. The English-language literature on the subject defines this phenomenon as earnings management.

Because of the growth in importance of information generated by financial reporting as regards decision usefulness, and spectacular instances of accounting fraud committed by management boards of American companies, resulting in their collapse at the beginning of the 21st century, earnings management is a major area of research in contemporary accounting (Dechow et al.2012, pp. 275-276; Kamela-Sowińska 2003, p. 4; Piosik 2016, p. 9; Vladu \& Cuzdriorean 2014, p. 696).

An analysis of the literature on the subject leads me to propose the following research hypothesis: the compliance of actions undertaken as part of earnings management with the applicable legal regulations in the field of accounting and with the accounting policy adopted by an entity makes it possible to distinguish earnings management from fraud. The main objective of the article, then, is to highlight differences between earnings management and fraud. The research objectives are achieved in three ways. The article describes the essence of and defines earnings management, characterises fraud and earnings management from the viewpoint of legal regulations related to auditing, and reveals the relationship between fraud and earnings management. The research methods applied are based on a critical analysis of the literature on the subject, both in Polish and English, a comparative analysis of legal acts and inductive reasoning. 


\section{Earnings Management as an Intentional and Lawful Action of the Management Board}

Financial statements are an important source of information about an entity's financial standing and economic position, as well as its earnings. This information is essential for assessment of the entity's activity and determines investment decisions (Remlein 2015, p. 150). A significant element of financial statements are earnings, which prove the effectiveness of an entity's activities. Management boards strive to improve results, which can lead them to employ earnings management (Emerling 2016, pp. 23-24).

Earnings management is a complex and multi-dimensional phenomenon that is difficult to measure. As a result, it is variously understood and defined by theoreticians, practitioners and accounting regulators (Callao, Jarne \& Wróblewski 2014, pp. 135-136).

Earnings management was initially equated with management consciously intervening in the process of preparing the financial statement in an effort to obtain certain benefits. But intervention interferes with the neutral course of this process (Schipper 1989, p. 92). It has also been pointed out that the occurrence of earnings management is conditioned by the asymmetry of information between an entity's management and other users of financial statements (Schipper 1989, p. 95). I believe that preparing the financial statement requires the active participation of managers, as they are responsible for presenting in the financial statement, in a reliable and faithful manner, information about the financial position and the financial result achieved by the entity. In addition, information asymmetry enables managers to use information about the company in financial reporting that is unavailable to others to achieve their own objectives.

It has also been argued that earnings management occurs when managers, using judgment in financial reporting and in structuring transactions, change financial statements in order to create a desired picture of an entity's financial standing. In so doing, they misinform some stakeholders or obtain benefits guaranteed in managerial contracts, the realisation of which depends on the fulfillment of specific conditions provided for in these contracts (Healy \& Wahlen 1999, p. 368). Research has shown that managers manage earnings by using (Healy \& Wahlen 1999, pp. 368-369):

- judgment (estimates) in financial reporting - for example, in establishing the period of economic usefulness, residual value or asset impairment, and determining pension benefits liabilities;

- acceptable accounting methods allowed under the applicable accounting regulations, including amortisation / depreciation methods, methods of valuating balances and methods of pricing the quantity and outflow of inventory; 
- structuring economic transactions with the aim of selecting and designing so that their effects are disclosed in accounting books in a manner planned in advance.

Preparing the financial statement involves choosing from among the methods permitted in the applicable accounting regulations or establishing reliable estimates for some items of this report in order to faithfully reflect the financial situation and the financial results to be reported. To create the desired image of the entity in the financial statement in order to influence stakeholders and induce specific actions or achieve personal benefits, the entity's management board exhibits some subjectivity in choosing from among alternative solutions acceptable in accounting regulations, estimating or structuring transactions. Given that, Wójtowicz has argued that earnings management is the effect of conscious and planned activity of those responsible for reporting in an entity. This activity is reflected in the choices made in the field of financial reporting and is eventually disclosed in the earnings presented (Wójtowicz 2010, p. 83).

Others maintain that earnings management is justified and the decisions made by an entity's management board as regards financial reporting with the aim of achieving stable and predictable earnings are lawful (McKee 2005, p. 1, after: Kuzior 2011, p. 175). This means, therefore, that earnings management fails to cover illegal actions violating the applicable law, and an entity's management can manage its earnings by (McKee 2005, p. 4, after: Kuzior 2011, p. 175; Park 2017, p. 1215):

- selecting specific methods, rules and models laid down in the accounting standards,

- making appropriate operating decisions.

Earnings management manifested in the decisions made by the entity's management board regarding the rights to choose or professional judgment (described in the accounting policy) or operating activities that do not violate accounting regulations should not be considered illegal activities. A certain degree of flexibility existing in accounting regulations, on the one hand, is aimed at enabling the entity's management to more fully implement the principle of a true and fair view, while taking into account the specificity of its activities. It also provides an opportunity to create the desired financial results. In the subject literature, earnings management is identified with an objective or a set of objectives adopted by an entity's management board and an integrated set of instruments for its or their achievement related to the methods adopted, and, in particular, with accounting estimates (accounting instruments) and the transactions conducted (material instruments). In consequence, (short-term) earnings, which are known to management, are not disclosed, though they would have been in a financial statement if a specific sub-group of objectives and instruments had not been applied. 
Nevertheless, earnings are managed in correspondence with the balance-sheet policy adopted by a given entity, in particular in the case of accounting instruments, and therefore in compliance with the applicable balance-sheet laws (Piosik 2016, p. 22).

Several key aspects of earnings management are worth focusing on here (Grabiński 2010, p. 76):

- the occurrence, in the field of financial reporting, of areas which are subject to discretion and require the application of professional judgment and estimates contributes to the emergence of the phenomenon of earnings management;

- the need to apply professional judgment and estimates in financial reporting may be used by an entity's management board to provide external stakeholders with information. That information, on the one hand, is inside information known only to the entity's management, thereby potentially resulting in an improved quality of the financial statement. At the same time, it can be false information used to mislead stakeholders;

- benefits guaranteed in managerial contracts are significant incentives for managers to achieve the objectives provided for in the contracts and expressed with the values of the reporting items, and to influence the values of those items;

- earnings management may contribute to an increase or decrease in the transparency of financial statements;

- leveraging earnings management, an entity's management may influence the behaviour of both current and potential investors;

- earnings management can be perceived in a positive light when it has a favourable influence on an entity's value in the long term, or in a negative light when the management board undertakes opportunistic actions.

In the context of the above considerations and for the purposes of this article, earnings management can be defined as intentional actions undertaken by an entity's management board, which consist in selecting and applying appropriate methods and estimates, or undertaking real activities, leading to changes in financial statement items, and, in particular, in the earnings disclosed, in order to present the desired picture of the entity's financial standing and, thereby, misinform some stakeholders or obtain benefits guaranteed in managerial contracts. Earnings management does not encompass illegal actions, and is in compliance with the accounting policy adopted by an entity. Therefore, it should not be identified with fraud. 


\section{Fraud and Earnings Management in Legal Regulations Related to Auditing}

The term "fraud" denotes consciously misleading a person or using an error that person has made for one's own benefit (Słownik języka polskiego PWN 2020). In turn, the Polish Penal Code (The Act of 6 June, 1997, Art. 286, paragraph 1) defines fraud, in its broad sense, as causing another person to disadvantageously dispose of his own or someone else's property with the purpose of the perpetrator gaining a material benefit by misleading this person, or by taking advantage of a mistake or inability to adequately understand the action undertaken.

Fraud-related provisions and requirements are also included in national and international legal regulations on auditing. The National Auditing Standard (NAS) 240 in Poland was adopted in the wording of the International Standard on Auditing (ISA) 240 "The Auditor's Responsibilities Relating to Fraud in an Audit of Financial Statements" . According to this standard, fraud is an intentional act by one or more individuals among management, those charged with governance, employees, or third parties, involving the use of deception to obtain an unjust or illegal advantage (ISA 240, paragraph 11a). Like the Polish Penal Code, ISA 240 presents a wide definition of fraud. However, according to the provisions contained in legal regulations related to auditing, only two types of fraud, resulting in significant distortions in financial statements, fall within the auditors' area of interest (ISA 240, paragraph 3): fraudulent financial reporting and the misappropriation of assets.

Fraudulent financial reporting is understood as producing intentional misstatements, including omissions of amounts or disclosures in financial statements, to deceive financial statement users (ISA 240, paragraph A2). Misappropriation of assets denotes the theft of an entity's assets and is often perpetrated by employees at various levels within an entity (ISA 240, paragraph A5).

According to ISA 240, fraudulent misstatements in financial statements may consist in (Wąsowski 2010, pp. 15-16):

- manipulation, falsification or alteration of source data or documents based on which financial statements are prepared,

- misrepresentation in or intentional omission from financial statements of events, transactions and other significant information,

- the recording of fictitious transactions,

1 The National Council of Statutory Auditors in Poland, by way of its resolution no. 3430/52a/2019 of 21 March 2019 on auditing standards and other documents, introduced NAS 240 (National Auditing Standard 240) in the wording of ISA 240 issued by the International Auditing and Assurance Standards Board (IAASB). 
- the misapplication of accounting principles (policy) relating to amounts, classification, manner of presentation or disclosure,

- the misappropriation of assets.

This standard addresses a peculiar symptom of actions undertaken by an entity's management - that is, earnings management, which is aimed at deceiving financial statement users by influencing their perception of the entity's performance and profitability. In the beginning, earnings management may manifest itself in insignificant actions or inappropriate adjustments of assumptions or changes in judgments made by an entity's management. However, an increasing number of new pressures and incentives may cause an increase in the scale of these actions, and, consequently, lead to fraudulent financial reporting, which consists in an entity's management intentionally and materially misstating the entity's financial statements (ISA 240, paragraph A2). It should therefore be emphasised that, according to ISA 240, earnings management may lead to fraudulent financial reporting, but it is not in and of itself the same phenomenon (Wójtowicz 2009, p. 97). This standard also indicates that earnings management may manifest itself in (ISA 240, paragraph A2):

- reporting reduced revenues in a bid to minimise taxes;

- inflating earnings in order to meet market expectations, maximise management compensation when it is tied to the entity's performance, or secure bank financing.

To sum up the above, based on an analysis of legal regulations related to auditing, fraud should not be identified with earnings management. Nevertheless, according to ISA 240, the intensification of actions undertaken as part of earnings management, manifesting themselves in operating activities or changes in previously adopted methods or estimates, may lead to fraudulent financial reporting, which is fraud, and of interest to auditors.

\section{Fraud versus Earnings Management}

The above considerations lead to the conclusion that a common feature of earnings management and fraud is intentional action, as both of the cases are about the intentional presentation of an intended picture of an entity's financial standing with the aim of misleading financial statement users or realising management's interests. By contrast, the differences between these two phenomena include the scope of departure from the truth, methods applied and persons responsible (Wójtowicz 2007, p. 36, 2009, p. 97).

Fraud occurs when the actions undertaken by persons responsible for financial reporting in an entity, including the management board, violate accounting 
principles and are contrary to the provisions of law (Stolowy \& Breton 2004, p. 9; Wójtowicz 2007, p. 37). Earnings management, on the other hand, consists in an entity's management undertaking specific actions, both intentionally and regularly, within the framework of legal regulations in the field of accounting and taking account of solutions adopted in accounting policy (Guan, He \& Yang 2006, p. 569, after: Kassem 2012, p. 31; Koumanakos, Siriopoulos \& Georgopoulos 2005, p. 663, after: Kassem 2012, p. 31; Wójtowicz 2009, p. 97, 2010, p. 86). These are legal actions related to the management board taking advantage of discretion while making estimates (professional judgment) in financial reporting, taking opportunities to choose specific methods from among the acceptable accounting methods allowed by the applicable accounting regulations, or the structuring of economic transactions with the aim of achieving planned profits or specific objectives (Healy \& Wahlen 1999, pp. 368-369; Jones 2011, p. 7, after: Kassem 2012, p. 31; Stolowy \& Breton 2004, p. 11). The majority of researchers agree that earnings management ends at the moment of departing from or violating accounting principles or standards (for example, Beneish 1999, Rosner 2003, after: Piosik 2016, p. 20; McKee 2005, after: Piosik \& Strojek-Filus 2013, p. 14; Fijałkowska 2006, Piosik 2016).

So, the literature on the subject usually distinguishes earnings management from fraud. At the same time, numerous studies, along with the above-mentioned legal regulations on auditing, indicate that, although actions undertaken by management boards as part of earnings management do not violate the standards and provisions contained in accounting regulations, those actions can lead to the presentation in financial statements of inaccurate and unfair information about an entity's earnings and financial standing, and, consequently, mislead stakeholders, and, in particular, both current and potential investors (Healy \& Wahlen 1999, pp. 368-369; Lo, Ramos \& Rogo 2017, pp. 3, 24; Nelson \& Skinner 2013, p. 35). Furthermore, earnings management may in certain circumstances turn into fraud, especially when the actions undertaken by management, including creative accounting $^{2}$, fail to bring the desired effects in the form of achieving planned figures (DeFond 2010, p. 406; Jones 2011, p. 7, after: Kassem 2012, p. 32). It is therefore argued in the literature that the bounds enabling distinction between earnings management and fraud are defined by the intentions (motives) of management (Kassem 2012, p. 32; Higson 2003, p. 129, after: Kassem 2012, p. 32; Piosik 2016, p. 22; Wójtowicz 2010, p. 86). However, intentions are not quantifiable, so

${ }^{2}$ Creative accounting consists in taking advantage of the rights to choose, "fields of free action" and legal loopholes in national and international accounting regulations in order to disclose financial data in financial statements so that it provides the most favourable picture of an enterprise (Śnieżek \& Wiatr 2011, p. 115, 119). 
they are not subject to research (Dechow \& Skinner 2000, p. 238; Wójtowicz 2010, p. 86).

To sum up, while both earnings management and fraud involve consciously undertaking action, earnings management should not be considered on a par with fraud, as fraud is identified with illegal actions that are beyond the scope of actions undertaken as part of earnings management.

\section{Summary}

Earnings management involves intentional and lawful actions undertaken by an entity's management, aimed at changing the figures reported, and, in particular, earnings, in order to present the desired picture of the entity's financial standing and economic position, as well as its achievements in financial statements for the purpose of misleading financial statement users or obtaining benefits guaranteed in managerial contracts. This is achieved by way of applying accounting judgment and estimates, changing these estimates, choosing specific methods from among the acceptable accounting methods allowed by the applicable accounting regulations, structuring of economic transactions or undertaking actual activities.

According to ISA 240, fraud is an intentional act by one or more individuals among management, those charged with governance, employees, or third parties, involving the use of deception to obtain an unjust or illegal advantage. However, the auditor only deals with two types of fraud that result in significant distortions in financial statements: fraudulent financial reporting and the misappropriation of assets. Moreover, this standard identifies a particular manifestation of the activities of an entity's management, namely, earnings management, which, through insignificant actions, inappropriate adjustments of assumptions or changes in judgments made by an entity's management board, is aimed at deceiving financial statement users by influencing their perception of the entity's performance and profitability. ISA 240 indicates that intensification of actions undertaken as a part of earnings management, manifesting themselves in operating activities or changes in previously accepted methods or estimates, may lead to fraudulent financial reporting, and therefore fraud.

As a result of the research conducted, it has been established that earnings management should not be identified with fraud. While a common feature of these two phenomena is the consciousness of action, in contrast to fraud, earnings are managed within the framework of legal regulations in the field of accounting and taking account of solutions adopted in the accounting policy of a given entity. However, any abuse in this field, whether it involves departing from or violating the accounting principles or standards, may lead to intentional misstatements in 
financial statements - that is, fraud in its broad sense. The results obtained from the conducted research have allowed us to achieve the objective of the study and verify the research hypothesis, which was: the compliance of actions undertaken as part of earnings management with the applicable legal regulations in the field of accounting and with the accounting policy adopted by an entity makes it possible to distinguish earnings management from fraud.

The subject literature indicates that earnings management can be distinguished from fraud on the basis of management's intentions (motives). However, intentions are not quantifiable, and can therefore not be subject to research. The main difference between earnings management and fraud is the compliance of actions undertaken as part of earnings management with the applicable legal regulations and with the accounting policy adopted by an entity. Earnings management takes place within the framework of operating activity or uses a certain degree of flexibility existing in accounting regulations in order to create the desired picture of the entity in the financial statement. This picture may be intended to influence stakeholders and motive them to undertake specific actions or for managers to reap personal benefits. The management of an entity may seek to realise its own objectives by choosing from among alternative solutions that are acceptable in accounting regulations, as well as estimating or structuring transactions. This is an inspiration for further development of research on earnings management from the viewpoint of the determinants or instruments applied.

\section{Bibliography}

Beneish M. D. (1999), Incentives and Penalties Related to Earnings Overstatements that Violate GAAP, "The Accounting Review", vol. 74, no 4, https://doi.org/10.2308/ accr.1999.74.4.425.

Callao S., Jarne J. I., Wróblewski D. (2014), The Development of Earnings Management Research: A Review of Literature from Three Different Perspectives, "Zeszyty Teoretyczne Rachunkowości”, vol. 79, no 135, https://doi.org/10.5604/16414381.1133395.

Dechow P. M., Hutton A. P., Kim J. H., Sloan R. G. (2012), Detecting Earnings Management: A New Approach, "Journal of Accounting Research", vol. 50, no 2, https://doi. org/10.1111/j.1475-679X.2012.00449.x.

Dechow P. M., Skinner D. J. (2000), Earnings Management: Reconciling the Views of Accounting Academics, Practitioners, and Regulators, "Accounting Horizons", vol. 14, no 2, https://doi.org/10.2308/acch.2000.14.2.235.

DeFond M. L. (2010), Earnings Quality Research: Advances, Challenges and Future Research, "Journal of Accounting and Economics", vol. 50, nos 2-3, https://doi. org/10.1016/j.jacceco.2010.10.004.

Emerling I. (2016), Kształtowanie wyniku finansowego przedsiębiorstwa a oszustwa finansowe, "Studia Ekonomiczne. Zeszyty Naukowe Uniwersytetu Ekonomicznego 
w Katowicach", no 253, https://www.ue.katowice.pl/fileadmin/user_upload/wydawnictwo/SE_Artyku\%C5\%82y_251_270/SE_253/02.pdf (accessed: 18.10.2020).

Fijałkowska J. (2006), Zarzq̨dzanie zyskiem w warunkach globalizujących się rynków kapitałowych - motywy, techniki i sposoby identyfikowania, "Zeszyty Teoretyczne Rachunkowości", vol. 35, no 91.

Grabiński K. (2010), Zarzq̨dzanie zyskami jako jeden z kierunków rozwoju pozytywnej teorii rachunkowości, "Zeszyty Teoretyczne Rachunkowości”, vol. 56, no 112.

Guan L., He D., Yang D. (2006), Auditing, Integral Approach to Quarterly Reporting, and Cosmetic Earnings Management, "Managerial Auditing Journal”, vol. 21, no 6, https:// doi.org/10.1108/02686900610674861.

Healy P. M., Wahlen J. M. (1999), A Review of the Earnings Management Literature and its Implications for Standards, "Accounting Horizons", vol. 13, no 4, https://doi. org/10.2308/acch.1999.13.4.365.

Higson A. (2003), Corporate Financial Reporting: Theory and Practice, Sage Publications Ltd, London.

Jones M. J. (2011), Creative Accounting, Fraud and International Accounting Scandals, John Wiley \& Sons Ltd, The Atrium, Southern Gate, Chichester.

Kamela-Sowińska A. (2003), Skq̨d się wzięła sprawa „Enronu”?, "Rachunkowośc”, no 4.

Kassem R. (2012), Earnings Management and Financial Reporting Fraud: Can External Auditors Spot the Difference?, "American Journal of Business and Management", vol. 1, no 1, https://www.researchgate.net/publication/256029162_Earnings_Management_and_Financial_Reporting_Fraud_Can_External_Auditors_Spot_the_Difference (accessed: 18.10.2020).

Koumanakos E., Siriopoulos C., Georgopoulos A. (2005), Firm Acquisitions and Earnings Management: Evidence from Greece, "Managerial Auditing Journal", vol. 20, no 7, https://doi.org/10.1108/02686900510611212.

Krajowy Standard Badania 240 w brzmieniu Międzynarodowego Standardu Badania 240, Obowiązki biegłego rewidenta podczas badania sprawozdania finansowego dotyczące oszustw (The National Auditing Standard 240 in the wording of the International Standard on Auditing 240, The Auditor's Responsibilities Relating to Fraud in an Audit of Financial Statements), Uchwała nr 3430/52a/2019 Krajowej Rady Biegłych Rewidentów z dnia 21 marca 2019 r. w sprawie standardów badania oraz innych dokumentów, https:// www.pibr.org.pl/assets/meta/4138,1.5\%20KSB\%20240.pdf (accessed: 18.10.2020).

Kuzior A. (2011), Wycena operacyjnych aktywów trwałych a możliwości kształtowania zysków bilansowych w jednostkach stosujących MSSF, "Zeszyty Naukowe Uniwersytetu Szczecińskiego no 668. Finanse, Rynki Finansowe, Ubezpieczenia”, no 41, http:// wneiz.pl/nauka_wneiz/frfu/41-2011/FRFU-41-175.pdf (accessed: 18.10.2020).

Lo K., Ramos F., Rogo R. (2017), Earnings Management and Annul Report Readability, "Journal of Accounting and Economics", vol. 63, no 1, https://doi.org/10.1016/ j.jacceco.2016.09.002.

McKee T. E. (2005), Earnings Management: An Executive Perspective, Thomson, Mason, Ohio.

Nelson M. W., Skinner D. J. (2013), How Should We Think about Earnings Quality? A Discussion of "Earnings Quality: Evidence from the Field", "Journal of Accounting and Economics”, vol. 56, nos 2-3, https://doi.org/10.1016/j.jacceco.2013.10.003. 
Park K. (2017), Earnings Quality and Short Selling: Evidence from Real Earnings Management in the United States, "Journal of Business Finance and Accounting", vol. 44, nos 9-10, https://doi.org/10.1111/jbfa.12264.

Piosik A. (2016), Kształtowanie wyniku finansowego przez podmioty sprawozdawcze w Polsce: diagnoza dobrej i złej praktyki w rachunkowości, Wydawnictwo Uniwersytetu Ekonomicznego w Katowicach, Katowice.

Piosik A., Strojek-Filus M. (2013), Procesy kształtowania wyników bilansowych i ich podstawowe cele (in:) Kształtowanie zysków podmiotów sprawozdawczych w Polsce: MSR/MSSF a Ustawa o rachunkowości, ed. A. Piosik, Wydawnictwo C.H. Beck, Warszawa.

Remlein M. (2015), Doświadczenia polskich grup kapitałowych w zakresie zintegrowanej sprawozdawczości, "Studia Oeconomica Posnaniensia", vol. 3, no 1, https://bazawiedzy.ue.poznan.pl/info/article/UEP955b39535b1040b8a971be6d4255f191/\#.X6sNAsRCeUk (accesed: 18.10.2020).

Rosner R. L. (2003), Earnings Manipulation in Failing Firms, "Contemprorary Accounting Research", vol. 20, no 2, https://doi.org/10.1506/8EVN-9KRB-3AE4-EE81.

Schipper K. (1989), Commentary on Earnings Management, "Accounting Horizons", vol. 3, no 4, http://connection.ebscohost.com/c/articles/4816073/commentary-earningsmanagement (accessed: 17.01.2019).

Słownik Języka Polskiego PWN (2020), Oszustwo, https://sjp.pwn.pl/szukaj/oszustwo.html (accessed: 18.10.2020).

Stolowy H., Breton G. (2004), Accounts Manipulation: A Literature Review and Proposed Conceptual Framework, "Review of Accounting and Finance", vol. 3, no 1, https://doi. org/10.1108/eb043395.

Śnieżek E., Wiatr M. (2011), Rachunkowość a tendencyjne kreowanie obrazu działalności przedsiębiorstwa, "Prace i Materiały Wydziału Zarządzania Uniwersytetu Gdańskiego", no 1(1).

Ustawa z dnia 6 czerwca 1997 r. - Kodeks karny (The Act of 6 June, 1997 - the Penal Code), Dz.U. z 1997 r. nr 88, poz. 553 z późn. zm.

Vladu A. B., Cuzdriorean D. D. (2014), Detecting Earnings Management: Insights from the Last Decade Leading Journals Published Research, "Procedia - Economics and Finance", vol. 15, https://doi.org/10.1016/S2212-5671(14)00542-5.

Wąsowski W. (2010), Kreatywna rachunkowość: fatszowanie sprawozdań finansowych, 2nd ed., Difin, Warszawa.

Wójtowicz P. (2007), Unikanie ujawniania strat w sprawozdaniach finansowych: wyniki analizy empirycznej, "Zeszyty Naukowe Uniwersytetu Ekonomicznego w Krakowie", no 752, https://r.uek.krakow.pl/bitstream/123456789/2450/1/153761544.pdf (accessed: 18.10.2020).

Wójtowicz P. (2009), Oszukańcza sprawozdawczość finansowa wobec teorii kontraktów i teorii agencji, "Zeszyty Naukowe Uniwersytetu Ekonomicznego w Krakowie", no 796, https://r.uek.krakow.pl/bitstream/123456789/2251/1/163970346.pdf (accessed: 18.10.2020).

Wójtowicz P. (2010), Wiarygodność sprawozdań finansowych wobec aktywnego kształtowania wyniku finansowego, Wydawnictwo Uniwersytetu Ekonomicznego w Krakowie, Kraków. 


\section{Podobieństwa i różnice pomiędzy kształtowaniem wyniku finansowego a oszustwem}

(Streszczenie)

Cel: Głównym celem artykułu jest wskazanie różnic pomiędzy kształtowaniem wyniku finansowego a oszustem.

Metodyka badań: Zastosowane metody badawcze opierają się na analizie krytycznej literatury przedmiotu, zarówno polsko-, jak i anglojęzycznej, analizie porównawczej aktów prawnych oraz metodzie rozumowania indukcyjnego.

Wyniki badań: Kształtowanie wyniku finansowego stanowi celowe i zgodne z prawem działanie kierownictwa jednostki, którego zadaniem jest doprowadzenie do zmian w raportowanych danych finansowych, w szczególności zaś w wyniku finansowym, aby przedstawić pożądany obraz sytuacji finansowej i majątkowej oraz dokonań jednostki w sprawozdaniu finansowym służący wprowadzeniu w błąd użytkowników tego sprawozdania bądź osiągnięciu korzyści zagwarantowanych w kontraktach menedżerskich. Realizowane jest ono poprzez stosowanie osądu (szacunków) w rachunkowości, dokonywanie zmian tych szacunków, wybieranie określonych metod spośród akceptowalnych metod rachunkowości dopuszczonych obowiązującymi regulacjami rachunkowości, strukturyzację transakcji bądź podjęcie realnej aktywności.

Wnioski: Kształtowania wyniku finansowego nie należy utożsamiać z oszustwem, gdyż odbywa się ono w ramach regulacji prawnych z zakresu rachunkowości oraz z uwzględnieniem rozwiązań przyjętych w polityce rachunkowości danego podmiotu. Jednakże nadużycia w tej kwestii, polegające na odstąpieniu czy też naruszeniu zasad bądź standardów rachunkowości, mogą prowadzić do umyślnego zniekształcenia sprawozdania finansowego, czyli oszustwa w szeroki znaczeniu.

Wkład w rozwój dyscypliny: Inspiracja do dalszego rozwijania badań nad kształtowaniem wyniku finansowego w odniesieniu do determinant lub zastosowanych narzędzi.

Słowa kluczowe: kształtowanie wyniku finansowego, sprawozdanie finansowe, oszustwo, oszukańcza sprawozdawczość finansowa. 